\title{
Article \\ Study on the Microstructure and Mechanical Properties of a Ti/Mg Alloy Clad Plate Produced by Explosive Welding
}

\author{
Hui Zhao ${ }^{1,2, *(-)}$, Chaochao Zhao ${ }^{1,2}$, Yang Yang ${ }^{1,2}$, Yizhuo Wang ${ }^{1,2}$, Liyuan Sheng ${ }^{3}{ }^{\circledR}$, Yixu Li ${ }^{1,2}$, Miao Huo ${ }^{1,2}$, \\ Keren Zhang ${ }^{1,2}$, Liwei Xing ${ }^{1,2}$ and Ge Zhang ${ }^{1,2}$ \\ 1 School of Material Science and Engineering, Xi'an Shiyou University, Xi'an 710065, China; \\ chaoaooo@163.com (C.Z.); yy292642630@163.com (Y.Y.); yz.wang@siat.ac.cn (Y.W.); yixuxuli@163.com (Y.L.); \\ huomiao8888@163.com (M.H.); zkrnwpu@163.com (K.Z.); xingliwei2004@126.com (L.X.); \\ 190609@xsyu.edu.cn (G.Z.) \\ 2 Xi'an Key Laboratory of High Performance Oil and Gas Field Materials, Xi'an Shiyou University, \\ Xi'an 710065, China \\ 3 Shenzhen Institute, Peking University, Shenzhen 518057, China; lysheng@yeah.net \\ * Correspondence: huier7921@126.com; Tel.: +86-18149032802
}

\section{check for}

updates

Citation: Zhao, H.; Zhao, C.; Yang, Y.; Wang, Y.; Sheng, L.; Li, Y.; Huo, M.; Zhang, K.; Xing, L.; Zhang, G. Study on the Microstructure and Mechanical Properties of a Ti/Mg Alloy Clad Plate Produced by Explosive Welding. Metals 2022, 12, 399. https://doi.org/10.3390/ met12030399

Academic Editor: Aleksander Lisiecki

Received: 25 January 2022

Accepted: 21 February 2022

Published: 25 February 2022

Publisher's Note: MDPI stays neutral with regard to jurisdictional claims in published maps and institutional affiliations.

Copyright: (C) 2022 by the authors. Licensee MDPI, Basel, Switzerland. This article is an open access article distributed under the terms and conditions of the Creative Commons Attribution (CC BY) license (https:// creativecommons.org/licenses/by/ $4.0 /)$.

\begin{abstract}
In this paper, the microstructure and properties of a $\mathrm{Ti} / \mathrm{Mg}$ alloy clad plate manufactured by explosive welding were studied. The bonding interface was inspected by ultrasonic examination (US). The microstructure and the composition of the clad were characterized by OM and SEM. Properties were inspected by tensile test, shearing test, microhardness test and electrochemical corrosion. The results showed that the bonding interface of the clad plate was made up of straight areas and wavy areas. In straight areas, element diffusion occurred across the bonding interface. Additionally, in wavy areas, a melting zone occurred in the $\mathrm{Mg}$ alloy layer near to the bonding interface. Lots of light particles embedded on the melting zone. Tensile test results were comparable with the Ti sheet and the ultimate tensile strength of the clad plate demonstrated an $18 \%$ increase. The shearing strength of the clad plate was about 68-87 MPa. The microhardness of the clad plate was higher than that of the original sheets from the interface to $300 \mu \mathrm{m}$ away. At over $300 \mu \mathrm{m}$, the microhardness of the clad plate decreased and approached the original sheets. Compared with the straight area, the hardness of the $\mathrm{Mg}$ alloy layer in the wavy area close to the interface increased by $12 \%$. Corrosion results showed that the corrosion potential $\left(E_{\text {corr }}\right)$ absolute value of the clad plate increased by $24 \%$, and the corrosion current density $\left(i_{\text {corr }}\right)$ value was 4 orders of magnitude lower, compared with the $\mathrm{Mg}$ alloy sheet. It was clear that the corrosion resistance of the clad plate was higher than that of the $\mathrm{Mg}$ alloy sheet. Cladding Mg alloy and Ti by explosive welding would improve the industrial applications of magnesium materials.
\end{abstract}

Keywords: titanium; magnesium alloy; explosive welding; clad plate; microstructure; mechanical property; electrochemical corrosion

\section{Introduction}

Magnesium $(\mathrm{Mg})$ and its alloys possess great potential application in Computer, Communication, Consumer electronic, automotive, biomedical, and aerospace fields due to their low density, high specific strength and stiffness, as well as excellent biocompatibility [1,2]. However, their high chemical activity and poor corrosion resistance limit their further applications. Owing to the porous or loose structure and inferior corrosion resistance of the oxide or hydroxide films generated on the surface, $\mathrm{Mg}$ and its alloys are susceptible to corrosion in the environment (acidic solutions or neutral solutions). Thus, it is necessary to take steps to improve the corrosion resistance of $\mathrm{Mg}$ and its alloys. Titanium (Ti) and its alloys have excellent corrosion resistance, low density, high specific strength, and heat resistance, and they are widely used in the aviation, aerospace and petrochemical industries. Ti and its alloys exhibit excellent resistance to corrosion attack in many aggressive 
media and are deserving of close attention as structural material in the design of chemical processing machinery [3,4]. Thus, it is attractive to clad the Mg alloys with a Ti layer to promote their corrosion resistance. Welding methods for dissimilar materials include fusion welding (such as argon-arc welding, plasma welding and laser welding), friction stir welding, ultrasonic spot welding, and clod metal-transfer welding. However, due to differences in density, melting point and thermal expansion, the fabrication of a layered $\mathrm{Mg}$ and Ti clad plate by traditional welding methods is still challenging. Explosive welding is noted for its capability of offering high strength bonding and cladding metals that are unweldable or are difficult to weld by other methods. It has been developed as a promising way to clad dissimilar materials [5-13]. Thus, some attempts have been made to clad other materials on $\mathrm{Mg}$ alloys by explosive welding. Arisova [5] reported that aluminum was successfully coated on magnesium alloys by explosive welding and investigated the effects of heat treatment on the nature of change in micro-mechanical properties and phase composition of $\mathrm{Mg} / \mathrm{Al}$ clad plate. Chen [6] joined the 1100 aluminum and AZ31 magnesium alloy using an explosive welding method and analyzed the welding parameters, including explosive thickness and stand off on the bonding surface. Mro'z [7] reported that a round $22.5 \mathrm{~mm}$-diameter and $160 \mathrm{~mm}$-length $\mathrm{Mg} / \mathrm{Al}$ bars had been produced using the explosive welding method. The shearing stress values of these $\mathrm{Mg} / \mathrm{Al}$ bars were about $60 \mathrm{MPa}$. Additionally, the metallographic examination showed that the bond quality in the samples after the explosive welding process was good. No discontinuities or separations in the bonding region were found. Rouzbeh [8] clad the AZ31B magnesium alloys with the AA1050 aluminum through explosive welding and observed that the interface was wavy, and no intermetallic layers formed in the interface. It indicated that an appropriate bonding was formed between aluminum and magnesium in the interface. However, a few references reported to clad titanium and magnesium alloys by explosive welding. Habib [9] attempted to make a three-layer $\mathrm{Ti} / \mathrm{Mg} / \mathrm{Mg}$ plate by using a $\mathrm{Mg}$ alloy as an interlayer material to reduce molten zones. The study showed that a desired wavy interface was difficult to form between the titanium and magnesium. Additionally, some molten zones were still formed in the interface. Zhang [10] used explosive welding to clad $\mathrm{Ti}$ and $\mathrm{Mg}$ alloys with the aid of an $\mathrm{Al}$ interlayer and investigated the bonding mechanism of $\mathrm{Ti} / \mathrm{Al} / \mathrm{Mg}$ clad plate. The study indicated that a periodic wavy between $\mathrm{Ti}$ and $\mathrm{Al}$ plate. Additionally, the bonding interface between $\mathrm{Al}$ and $\mathrm{Mg}$ demonstrated a similar wavy shape, but some localized melted zones also existed at this interface. However, for tow-layer explosive welding titanium and magnesium alloy, much work, including the microstructure variations near the bonding interface, mechanical properties and corrosion resistance, is still needed for further investigation.

In this work, a Mg alloy (AZ31B) was coated with pure titanium (ASME SA256 Gr1) by the explosive welding method. The interface microstructure was examined by optical microscopy and scanning electron microscopy. The properties, including tensile strength, shearing strength, microhardness and corrosion resistance, were tested to evaluate the weld quality.

\section{Experimental Procedure}

\subsection{Materials}

Pure titanium (ASME SB265 Gr1) in a solution-annealed condition and a magnesium alloy $(\mathrm{AZ} 31 \mathrm{~B})$ in hot rolling condition sheets were used for explosive welding. The chemical compositions of the Ti (ASME SB265 Gr1) and Mg alloy (AZ31B) are listed in Table 1. Ti and $\mathrm{Mg}$ alloy sheets were prepared with dimensions of $3 \mathrm{~mm} \times 340 \mathrm{~mm} \times 540 \mathrm{~mm}$ and $10 \mathrm{~mm} \times 310 \mathrm{~mm} \times 510 \mathrm{~mm}$, respectively. 
Table 1. The chemical compositions of $\mathrm{Ti}$ and $\mathrm{Mg}$ alloy sheets (wt. \%).

\begin{tabular}{|c|c|c|c|c|c|c|c|c|c|}
\hline \multirow{3}{*}{$\begin{array}{c}\text { Materials } \\
\mathrm{Ti}\end{array}$} & \multicolumn{9}{|c|}{ Chemical Element } \\
\hline & \multirow{2}{*}{\multicolumn{2}{|c|}{$\begin{array}{c}C \\
0.06\end{array}$}} & $\mathrm{H}$ & \multirow{2}{*}{\multicolumn{2}{|c|}{$\begin{array}{c}\mathrm{N} \\
0.015\end{array}$}} & $\mathrm{O}$ & \multirow{4}{*}{$\begin{array}{c}\text { Fe } \\
0.01 \\
\mathrm{Cu} \\
0.00157\end{array}$} & \multirow{2}{*}{\multicolumn{2}{|c|}{$\begin{array}{c}\mathrm{Ti} \\
\text { Bal. }\end{array}$}} \\
\hline & & & 0.010 & & & 0.16 & & & \\
\hline \multirow{2}{*}{ AZ31B } & $\mathrm{Al}$ & $\mathrm{Si}$ & $\mathrm{Ca}$ & $\mathrm{Zn}$ & $\mathrm{Mn}$ & $\mathrm{Fe}$ & & $\mathrm{Ni}$ & $\mathrm{Mg}$ \\
\hline & 2.81 & 0.03 & 0.02 & 0.91 & 0.282 & 0.002 & & 0.0005 & Bal. \\
\hline
\end{tabular}

\subsection{Explosive Welding Process}

Parallel arrangements were employed for the experiment. Figure 1 shows the assemble drawing of explosive welding. Ti and $\mathrm{Mg}$ alloy sheets were placed in parallel directions. The Mg alloy sheet was placed on the anvil and the Ti sheet was placed above with a parallel space of about $6 \mathrm{~mm}$ in height. The ANFO explosive layer was spread on the Ti sheet surface. Additionally, the explosives were packed in a wooden box with the same dimensions as the Ti sheet. The thickness of the explosive was $24 \mathrm{~mm}$, and the density was $0.73 \mathrm{~g} / \mathrm{cm}^{3}$. The velocity was approximately $2200 \mathrm{~m} / \mathrm{s}$. An electronic detonator was placed in the long edge of the Ti sheet. By igniting the electronic detonator, the detonator initiated the explosives, and the Ti sheet was accelerated to rapidly shock the $\mathrm{Mg}$ alloy plate. Based on previous research [14], the collision point velocity (Vcp) was $2104 \mathrm{~m} / \mathrm{s}$, dynamic collision angle $(\theta)$ was $16.2^{\circ}$. Thus, the Ti sheet impact velocity $\left(\mathrm{V}_{\mathrm{p}}\right)$ can be calculated by the following Equation (1) with the $\mathrm{V}_{\mathrm{cp}}$ and $\theta$ [15].

$$
\mathrm{V}_{\mathrm{p}}=2 \mathrm{~V}_{\mathrm{cp}} \sin (\theta / 2)
$$

The impact velocity of Ti sheet was $599 \mathrm{~m} / \mathrm{s}$.

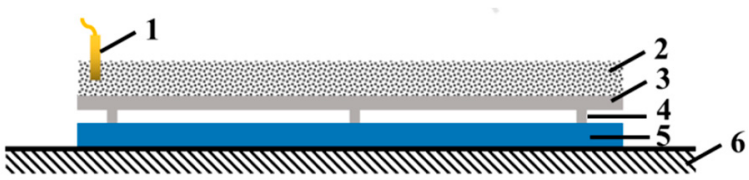

Figure 1. A drawing of explosive welding: 1 . detonator; 2 . explosives; 3 . Ti sheet; 4 . spacer; 5 . $\mathrm{Mg}$ alloy sheet; 6. anvil.

\subsection{Specimen Characterization}

After explosive welding, ultrasonic examination (US) was employed to inspect the bonding interface of clad plates with OLYMPUS 5077 equipment [5]. Then, the samples were cut parallel to the detonation direction. The cross-sections of samples were grounded with $\mathrm{SiC}$ sandpaper up to No. 2000 and polished with diamond paste. Additionally, they were etched with $3 \mathrm{~mL}$ hydrogen nitrate and $97 \mathrm{~mL}$ alcohol. The interface microstructure of the clad plate was observed by optical microscopy (Olympus GX51). The interface observation and elements analyses of the clad plate were conducted using scanning electron microscopy (SEM, SSX-550, shimadzu corporation, kyoto, Japan) An energy dispersed X-ray micro-analyzer (EDS) (shimadzu corporation, kyoto, Japan), was also carried out.

Three samples for the shearing test were prepared (shown in Figure 2). Shearing and tensile tests were carried out on a testing machine named DLY-10A, (Shanghai hesheng instrument technology co., 1td., Shanghai, China) The shearing speed was $0.2 \mathrm{~mm} / \mathrm{min}$. Microhardness measurement was carried out on the 401MVD Vickers durometer (Shanghai optical instrument factory, Shanghai, China), using a load of $50 \mathrm{~g}$ and a dwell time of $15 \mathrm{~s}$. A three-electrode system attached to an electrochemical workstation (CHI660E, Shanghai Chenhua instrument Co., Ltd., Shanghai, China) was used for the electrochemical corrosion measurement. The samples of original Ti sheet, $\mathrm{Mg}$ alloy sheet and clad plate were used as the working electrode, while the saturated calomel electrode and platinum electrode were used as reference electrode and counter electrode, respectively. The corrosive medium was $3.5 \mathrm{wt} . \% \mathrm{NaCl}$ solution at room temperature. The polarization curve was scanned 
from $-3.5 \mathrm{~V}_{S C E}$ to $2.0 \mathrm{~V}_{S C E}$ at a scan rate of $0.5 \mathrm{mV} / \mathrm{s}$. The corrosion potential $\left(E_{\text {corr }}\right)$ and corrosion current density $\left(i_{\text {corr }}\right)$ for each sample were obtained from the Tafel curve using CorrView software.

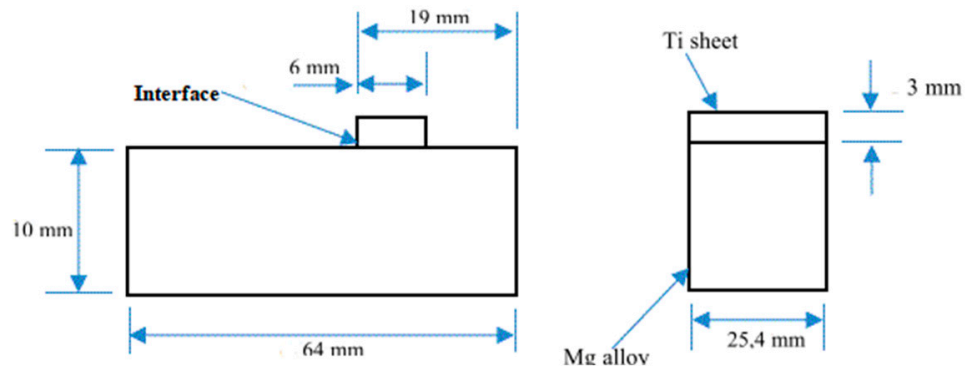

Figure 2. The drawing of shearing test sample.

\section{Results and Discussion}

After explosive welding, the Ti/Mg alloy clad plate with $310 \mathrm{~mm} \times 310 \mathrm{~mm} \times 510 \mathrm{~mm}$ was obtained. Figure 3 presents the appearance, ultrasonic examination (US) results and optical interface microstructure of the clad plate after explosive welding. Figure 3a shows the appearance of the clad plate. It shows that the $\mathrm{Ti}$ and $\mathrm{Mg}$ alloy layers are tightly joined together, and no cracks are detected. Ultrasonic examination (US) results also show that the interface reflection wave is obtained, which indicates that the clad plate bonds well (Figure 3b). All the results show that explosive welding is an effective method to join pure Ti and AZ31B Mg alloy sheets. The optical microstructure of the clad plate is shown in Figure 3c. It reveals the interface is made up of wavy areas and straight areas. In straight areas, the interface is smooth and uniform, and no cracks or unbonded defects. In wavy areas, the interface is asymmetric and spikes toward the Ti layer due to the density differences and the inclined collision between $\mathrm{Ti}$ and $\mathrm{Mg}$ alloy materials [6], but there are still some black areas in the $\mathrm{Mg}$ alloy layer close to the interface.
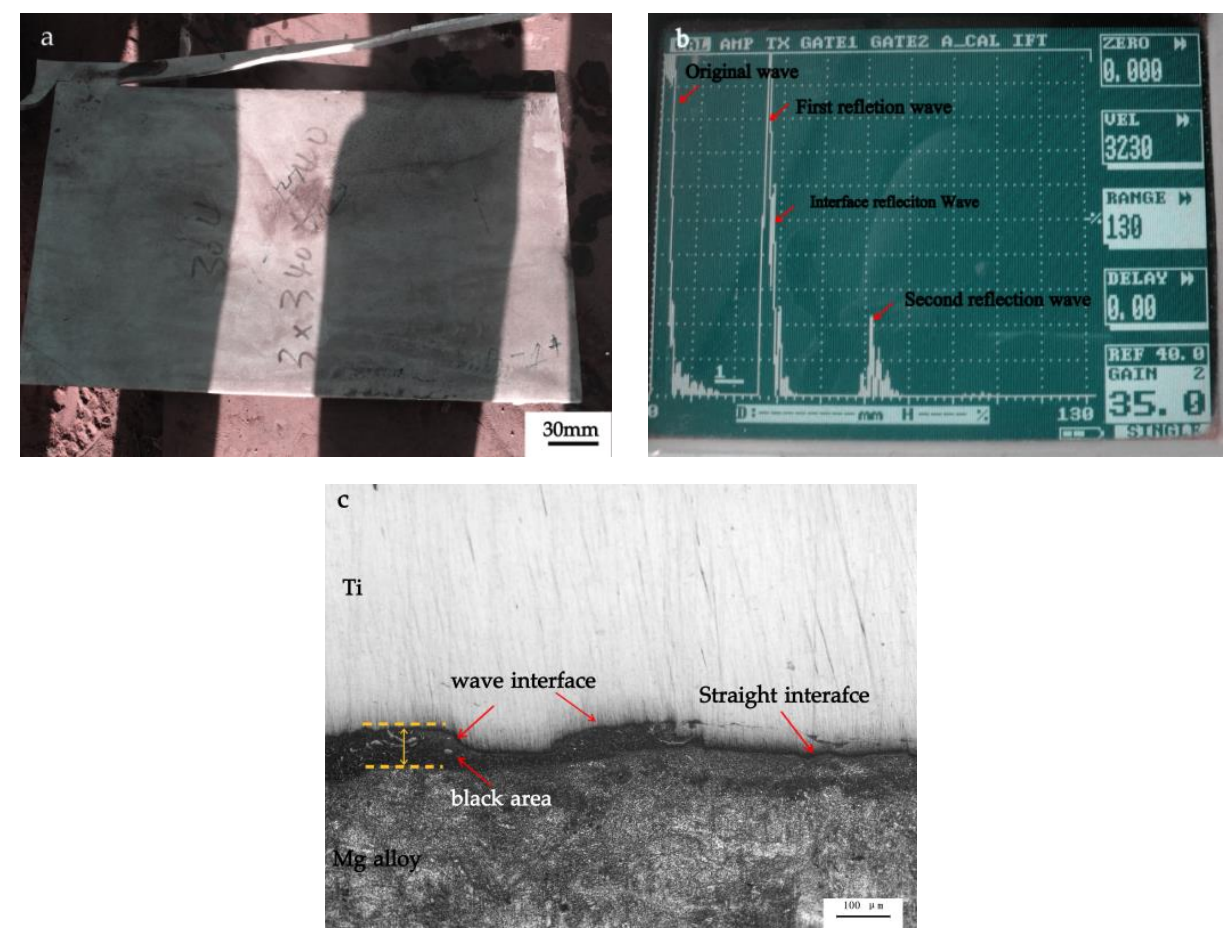

Figure 3. The clad plate after explosive welding: (a). the appearance; (b). the ultrasonic examination (US) results; (c). the optical interface microstructure. 
To clearly observe the morphology of the bonding interface, SEM and EDS analyses were used (Figure 4). Figure 4a,b shows the straight and wavy areas of the bonding interface, respectively. During the explosive welding process, high temperature and pressure are produced at the collision point, causing the jet to spray in the front of the collision point with a velocity greater than $5000 \mathrm{~m} / \mathrm{s}$ [6]. Due to inclined collision and resistance of the bonding surfaces, the jet changes its direction to penetrate the bonding surfaces, then the interface forms. Moreover, due to resistance of the bonding interface, the jet separated into two parts: most of the jet moved forward, and the left part penetrated the bonding surface to form the interface. The left part of the jet swirled back in a counterclockwise direction, continually penetrating the bonding surfaces to form straight or wavy interface [16]. The jet penetration is not uniform between participant metals due to the variation in the density and thermal conductivity [17]. The jet for penetration is bigger and the deformation of the bonding surface is more serious. So, the formation of the interface with straight and wavy microstructure is caused by the jet penetration degree. In this paper, both straight and wavy areas are generated in the interface. In straight areas, a straight interface is visible (Figure 4a). Additionally, in higher magnification, as shown in Figure 4c, the interface is uniform, with no cracks or melting zones. However, in wavy areas, the irregular wavy microstructure is demonstrated in Figure $4 \mathrm{~b}$. Additionally, there are also no cracks in the interface. However, a melting zone (the black area in Figure 3c) is found on the $\mathrm{Mg}$ alloy layer near the interface $[10,11]$. In higher magnification, Figure $4 \mathrm{~d}$ shows that lots of light particles embed on the melting zone. Microcracks and pores are also observed in the melting zone. EDS is used to analyze the elemental composition of the melting zone. Figure $4 \mathrm{e}-\mathrm{g}$ shows the results of EDS analyses for point 1, 2 and 3 in the melting zone. Point 1 is a black area in the melting zone. Additionally, the composition of point 1 is $89.46 \% \mathrm{Mg}, 7.52 \% \mathrm{O}$ and $3.02 \% \mathrm{Al}$ (Figure $4 \mathrm{e}$ ). It is similar to the original $\mathrm{Mg}$ alloy sheet. However, the compositions of light particles in the melting zone are different. The shapes of light particles are compact or loose. The EDS analysis of compact particle (point 2) is about $46.22 \% \mathrm{Mg}, 3.56 \% \mathrm{Al}, 36.37 \% \mathrm{Ti}$ and $13.83 \% \mathrm{O}$. Additionally, in the loose particle (point 3), $55.19 \% \mathrm{Mg}, 2.74 \% \mathrm{Al}, 31.78 \% \mathrm{Ti}$ and $10.29 \% \mathrm{O}$ are detected. According to the $\mathrm{Mg}-\mathrm{Ti}$ equilibrium diagram in the literature [18], it is deduced that the possible phases of $\mathrm{MgTi}$ and $\mathrm{Mg}_{2} \mathrm{Ti}$ are formed in point 2 and point 3.

Element line scanning analyses across the straight and wavy areas in the interfaces were conducted by EDS to investigate the element distribution (Figure $5 \mathrm{a}, \mathrm{c}$ ). The results are shown in Figure 5b,d. Across the straight areas, line scanning analysis indicates that the titanium layer of the clad plate is almost completely Ti and the magnesium alloy layer is almost $\mathrm{Mg}$. However, there are some differences near to the interface. It is noticed that element diffusion occurs across the interface, and no trace of intermetallic compound is observed. During the explosive welding, high temperature $(>1000 \mathrm{~K})$ and pressure $(>106 \mathrm{~Pa})$ are produced at the collision point, resulting in element distribution [6]. Moreover, there is not enough time to the generate intermetallic compound in the bonding interface due to the fast welding (about $10^{-6} \mathrm{~s}$ ) [6]. Thus, no intermetallic compounds were detected in the straight areas. On the other hand, across the wavy areas, the EDS line scanning results demonstrate that the distribution of $\mathrm{Ti}$ in titanium layer and $\mathrm{Mg}$ in magnesium alloy layer are similar to those in the straight areas. However, in the melting zone, element distributions are different. During the explosive welding, it is not easy to form intermetallic compounds in the bonding interface. However, many studies show the formation of intermetallic compounds in the melting zone $[6,19,20]$. Additionally, as mentioned above, the formation of wavy interface is resulted from the high-speed jet $(>5000 \mathrm{~m} / \mathrm{s})$ penetrating the bonding sheet. In wavy areas, the generated heat is not able to rapidly dissipate, causing the melting zone to form. Thus, the intermetallic compounds occur in this zone, and some micropores and cracks also appear [19]. As shown in Figure 5d, the contents of Ti and $\mathrm{Mg}$ in the melting zone are fluctuating along the scanning line. Ti elements only occur in the light particles on the melting zone, and the composition of black area is almost $\mathrm{Mg}$. This is in consistent with the result of EDS point analyses. It has been reported $[6,10,21,22]$ that 
the wavy interface is generally preferred in the explosive welding because it provides a larger interface area and higher bonding strength than straight ones. However, for Ti-Mg alloy clad plate, the melting zone, micropores and cracks occur in the wavy interface. They are the weaker locations in the clad plate. Thus, straight interface indicates a good bonding quality for Ti/Mg alloy clad plate.
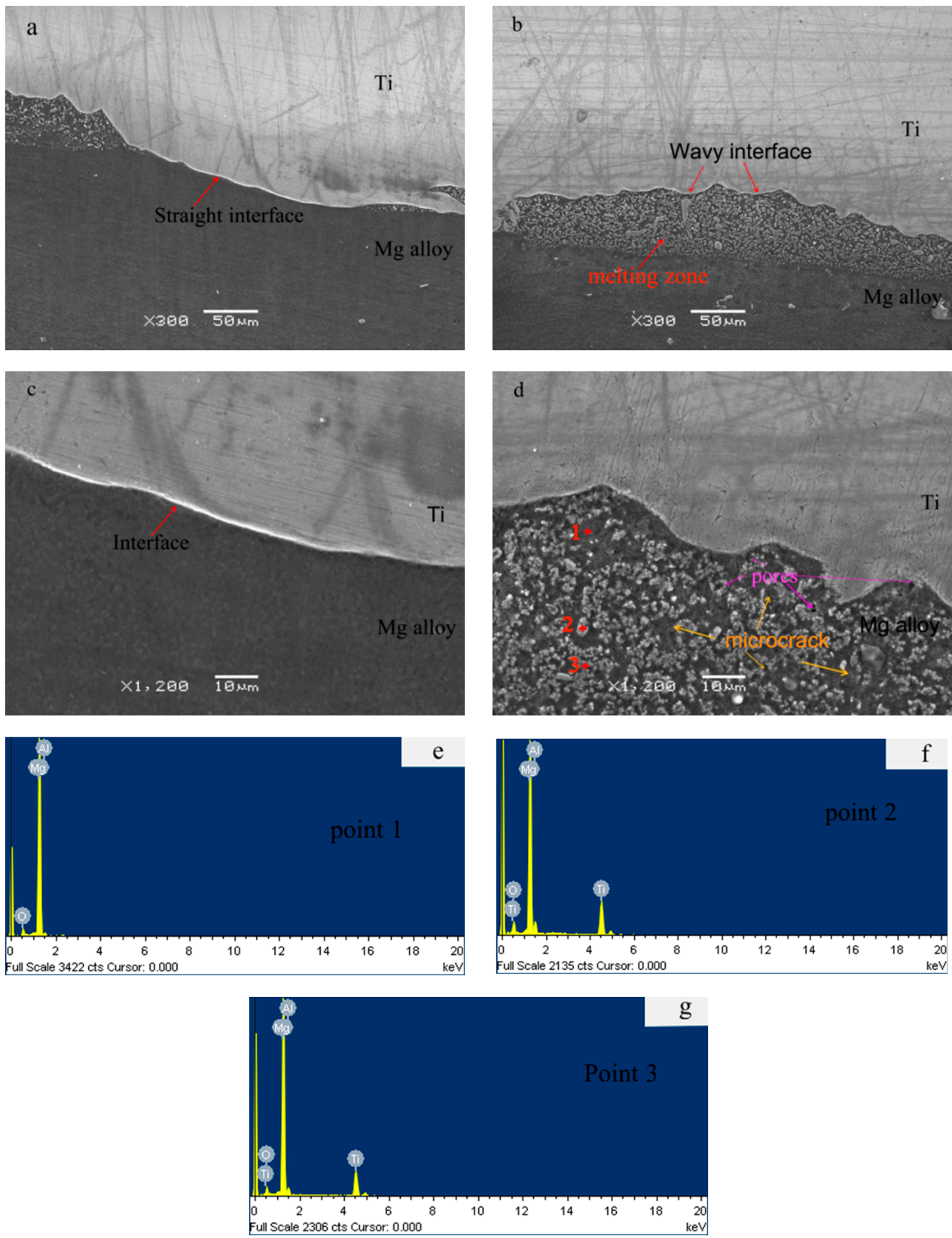

Figure 4. Interface microstructure (SEM) and corresponding EDS spectrum analyses: (a). straight area; (b). wavy area; $(\mathbf{c}, \mathbf{d})$.: enlarged views of $(\mathbf{a}, \mathbf{b})$, respectively; (e). EDS analysis of point 1 ; (f). EDS analysis of point 2; (g). EDS analysis of point 3. 

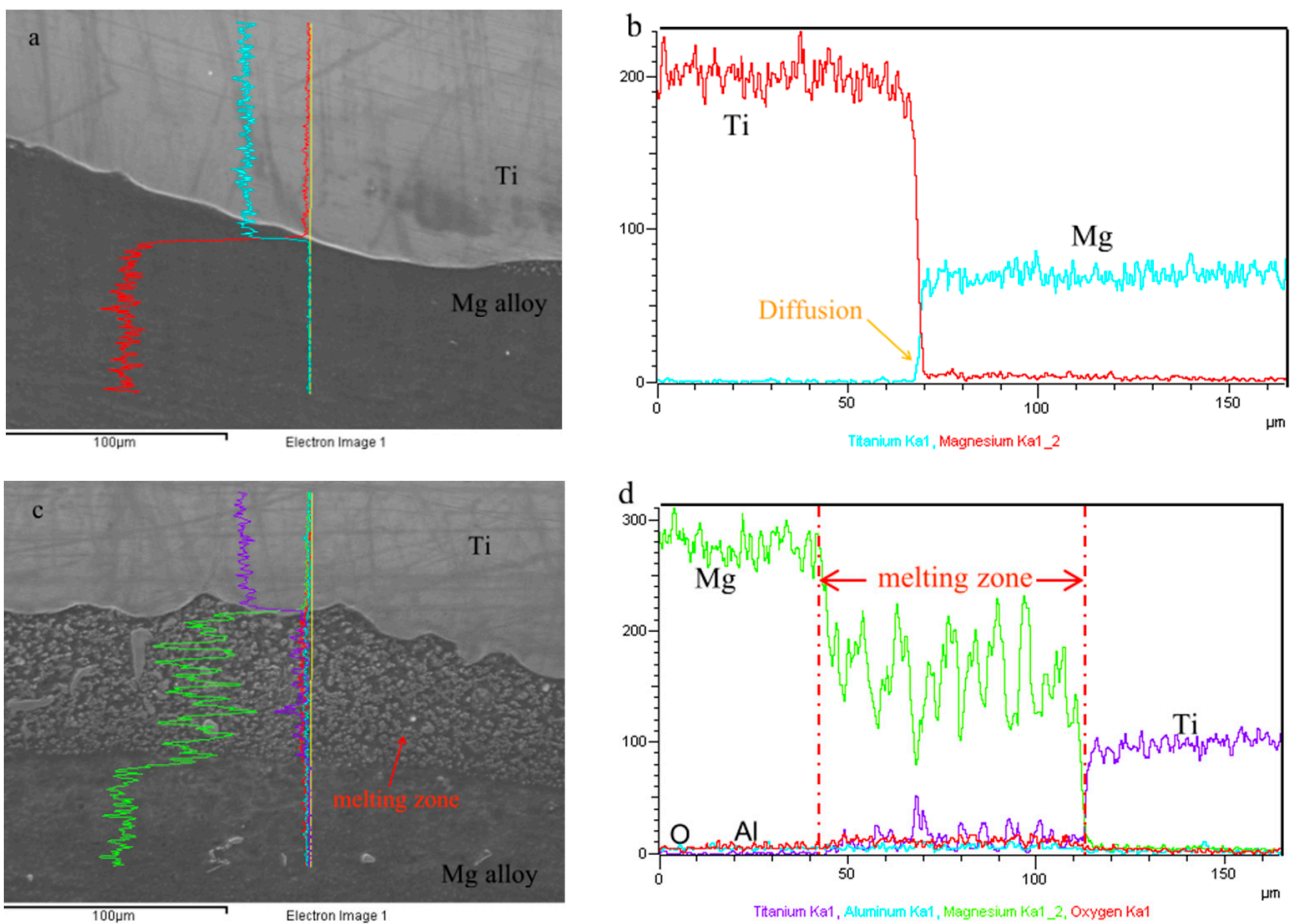

Figure 5. Line scanning results: (a). straight area of the interface, (b). wavy area of the interface, $(\mathbf{c}, \mathbf{d})$. are the line scanning results of straight and wavy areas, respectively.

Figure 6 shows tensile test curves, failed samples and SEM images of fracture surface morphology in the Ti sheet, Mg alloy sheet and clad plate. Stress-strain curves are shown in Figure 6a. It can be seen that explosive welding affects the deformation behavior of the sheets and clad plate. Additionally, the tensile properties of the Ti sheet, $\mathrm{Mg}$ alloy sheet and clad plate are summarized in Table 2. An obvious variation occurs in the tensile strength after explosive welding. Compared with the Ti sheet, the ultimate tensile strength increases from $320 \mathrm{MPa}$ to $377 \mathrm{MPa}$. This shows an 18\% increase. Additionally, compared with the $\mathrm{Mg}$ alloy sheet, the tensile strength of the clad plate also increases. Above phenomena are mainly due to work hardening from explosive welding. The failed samples of the Ti sheet, $\mathrm{Mg}$ alloy sheet and clad plate are shown in Figure $6 \mathrm{~b}$. According to the figure, the fractures of the Ti sheet and clad plate demonstrate obvious necking. However, the fracture of the $\mathrm{Mg}$ alloy sheet hardly deforms. An important point in this picture is that the separation occurs at the tip of the clad plate fracture, while other areas of the interface continue to join. This indicates that the clad plate performs good bonding quality. The fracture surfaces of the three samples, perpendicular to the tensile loading, are shown in Figure $6 \mathrm{c}-\mathrm{i}$. Additionally, as shown in Figure 6c, the fractures of Ti metal demonstrate obvious necking. The fracture surface is composed of a large number of dimples, showing a characteristic nature of ductile mode (Figure 6d), whereas the fracture in the Mg alloy sheet hardly deforms (Figure 6e). In the fracture surface, typical transgranular and cleavage features are witnessed, indicating brittle mode of fracture (Figure $6 \mathrm{f}$ ). For the clad plate, the shape of the $\mathrm{Mg}$ alloy layer changes slightly, and the shape of the Ti layer deforms radically, so there is obvious separation between the $\mathrm{Ti}$ and $\mathrm{Mg}$ alloy layers (Figure $6 \mathrm{~g}$ ). Additionally, the fractured surface of the clad plate shows a mixed mode consisting of brittle and ductile modes, as reported by Rouzbeh, Z. [8] and Wang, D. [23]. Figure 6h,i show enlarged views of local microstructure in the Ti and $\mathrm{Mg}$ alloy layers fractures, respectively. It can be seen that the fracture surface of the Ti layer is composed of a large number of dimples, which confirm the ductile fracture (Figure 6h). Additionally, clearly, at the fracture surface of the $\mathrm{Mg}$ alloy layer, fewer shallow dimples are observed. The formation of these shallow dimples indicates a slight plastic deformation in the $\mathrm{Mg}$ alloy layer during tensile testing (Figure 6i). 

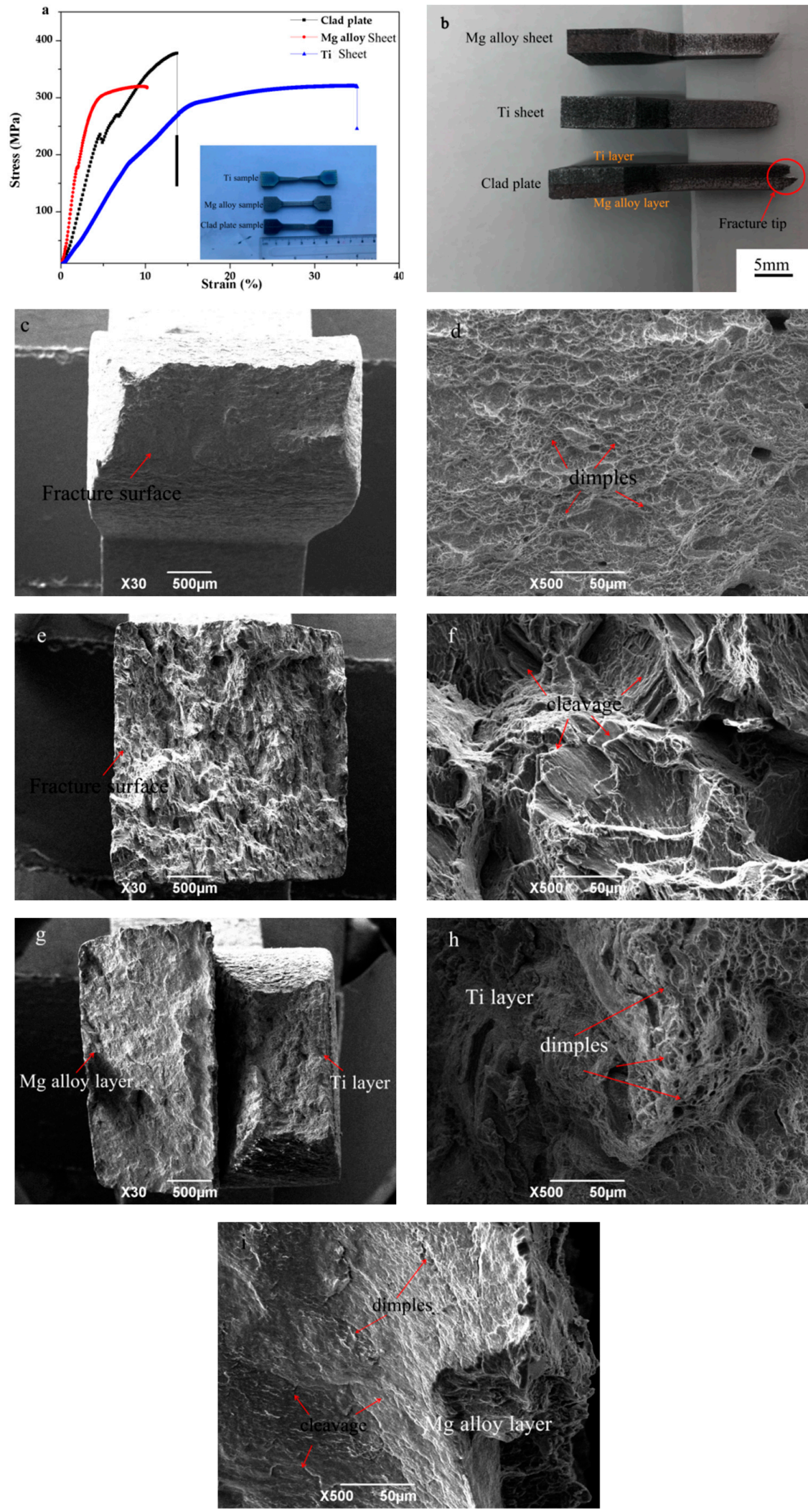

Figure 6. Tensile test of $\mathrm{Ti}, \mathrm{Mg}$ alloy and $\mathrm{Ti} / \mathrm{Mg}$ clad plates: (a). stress-strain curves; (b). failed samples after testing; (c,d): Ti layer fracture surfaces at low and high magnification, respectively; $(\mathbf{e}, \mathbf{f}): \mathrm{Mg}$ alloy layer fracture surfaces at low and high magnifications, respectively; (g). the fracture surface of clad plate at low magnification; $(\mathbf{h}, \mathbf{i})$ : the fracture surfaces of Ti layer and $\mathrm{Mg}$ alloy layer, respectively. 
Table 2. The tensile test results of Ti sheet, $\mathrm{Mg}$ alloy sheet and the clad plate.

\begin{tabular}{cccc}
\hline Sample & Yield Strength (MPa) & $\begin{array}{c}\text { Ultimate Tensile } \\
\text { Strength } \mathbf{( M P a )}\end{array}$ & Elongation (\%) \\
\hline Ti sheet & 189 & 320 & 34.53 \\
Mg alloy sheet & 174 & 319 & 10.20 \\
Clad plate & $/$ & 377 & $/$ \\
\hline
\end{tabular}

Shearing strength is a significant factor for evaluating the bonding interface and welding quality. Three samples for the shearing test are prepared according to Figure 2. Additionally, the measured shear strengths for sample 1, sample 2 and sample 3 are shown in Figure 7. During the shearing strength testing, all failures occur at the bonding interface. The values of sample 1, sample 2 and sample 3 are $68 \mathrm{MPa}, 87 \mathrm{MPa}$ and $69 \mathrm{MPa}$, respectively. Similar results $[9,24]$ have been reported for the shearing strength of the $\mathrm{Ti} / \mathrm{Mg}$ alloy clad plate.

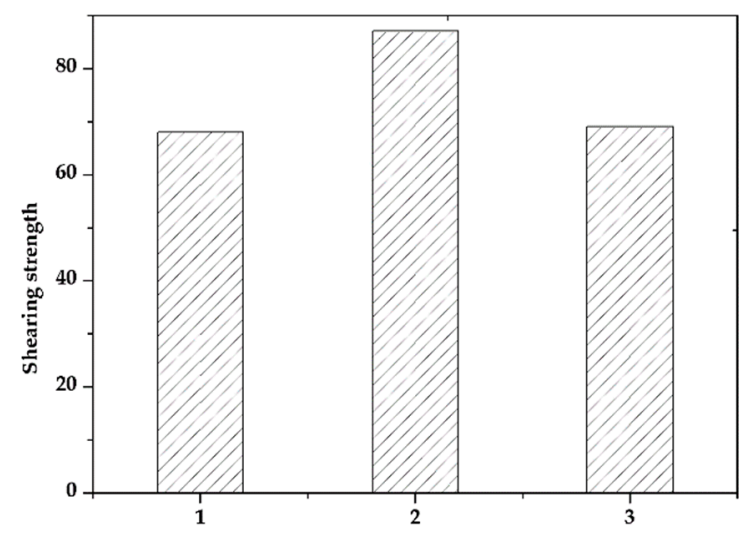

Figure 7. Shearing test results of clad plates.

The hardness values of the Ti sheet and Mg alloy sheet are $126 \mathrm{HV}$ and $90 \mathrm{HV}$, respectively. Hardness measurements are performed across the wavy and straight areas of the interface in the clad plate. Additionally, Figure 8 shows Vickers hardness changes with different distances away from the interface in the clad plate. In straight areas, the hardness value of the Ti layer is $212 \mathrm{HV}$ close to the interface. Towards the thickness center of the titanium layer, the hardness values are $208 \mathrm{HV}, 198 \mathrm{HV}, 193 \mathrm{HV}, 171 \mathrm{HV}, 154 \mathrm{HV}, 132 \mathrm{HV}$ and $130 \mathrm{HV}$ at $50 \mu \mathrm{m}, 100 \mu \mathrm{m}, 150 \mu \mathrm{m}, 200 \mu \mathrm{m}, 250 \mu \mathrm{m}, 300 \mu \mathrm{m}$ and $1000 \mu \mathrm{m}$ away from the bonding interface. In addition, at the same distance in the Mg alloy layer $(0 \mu \mathrm{m}, 50 \mu \mathrm{m}$, $100 \mu \mathrm{m}, 150 \mu \mathrm{m}, 200 \mu \mathrm{m}, 250 \mu \mathrm{m}, 300 \mu \mathrm{m}$ and $1000 \mu \mathrm{m}$ ), hardness values are measured, respectively, yielding the values of $117 \mathrm{HV}, 109 \mathrm{HV}, 101 \mathrm{HV}, 97 \mathrm{HV}, 99 \mathrm{HV}, 93 \mathrm{HV}, 90 \mathrm{HV}$ and $91 \mathrm{HV}$. Most values are higher than original sheets from the interface to $300 \mu \mathrm{m}$ away. At over $300 \mu \mathrm{m}$, the hardness value decreases, and approaches that of the original sheets. Additionally, the maximum microhardness values of Ti and $\mathrm{Mg}$ alloy layers all occurs close to the interface. This is due to the deformation resulting from the collision at high velocity during explosive welding [6,17]. In wavy areas, a similar variation of microhardness values is observed. However, compared with the straight areas, the values in the $\mathrm{Mg}$ alloy layer are higher from the bonding interface to $100 \mu \mathrm{m}$, reaching $131 \mathrm{HV}, 128 \mathrm{HV}$ and 106 at $0 \mu \mathrm{m}$, $50 \mu \mathrm{m}$ and $100 \mu \mathrm{m}$, respectively. The area is the melting zone in the Mg alloy layer. The hardness value close to the interface even increases by $12 \%$. The increase could be due to the presence of the hard and brittle Ti and Mg intermetallic phases in the melting zone. 


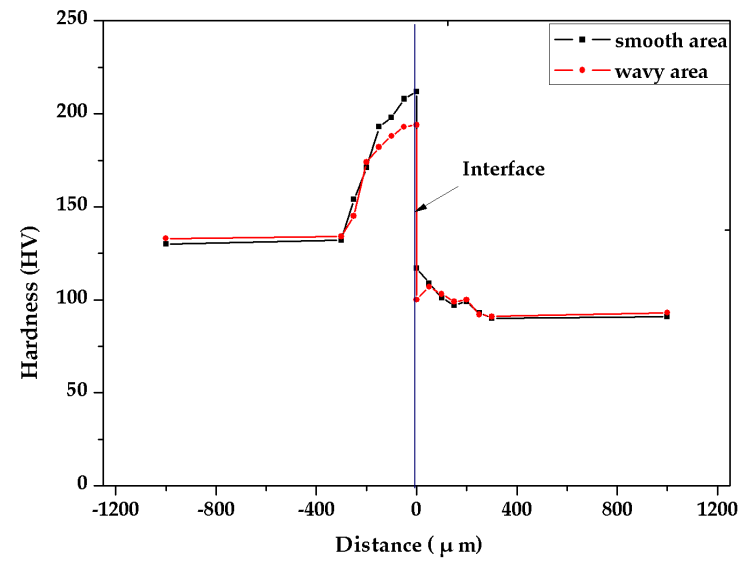

Figure 8. Hardness profiles around the interface with wavy and straight structures.

Although it is well known that titanium material has excellent corrosion resistance, a tremendous amount of heat and pressure released by explosives on the surface of the $\mathrm{Ti}$ sheet during explosive welding perhaps affects the corrosion resistance of titanium material. For comparison, the corrosion resistance of Ti materials before and after explosive welding is evaluated by electrochemical corrosion test. Figure 9 shows the polarization curves of the original $\mathrm{Ti}$ sheet, $\mathrm{Mg}$ alloy sheet and clad plate. It can be seen that the $\mathrm{Mg}$ alloy sheet possesses active dissolution, and its anodic current density increases rapidly with the increase in anodic overpotential. The original Ti sheet and clad plate behave similarly, having a wide potential range of passive regions. The polarization curves are fitted using CorrView software, and the corrosion potential and corrosion current density are obtained, as shown in Table 3 . It shows that the corrosion potential $\left(E_{c o r r}\right)$ and corrosion current density $\left(i_{\text {corr }}\right)$ of three samples are different. $E_{\text {corr }}$ values of the Ti sheet, $\mathrm{Mg}$ alloy sheet and the clad plate are $-746.1 \mathrm{~m} V_{S C E},-1177.7 \mathrm{~m} V_{S C E}$ and $-896.3 \mathrm{~m} V_{S C E}$, respectively. $E_{\text {corr }}$ value of the clad plate is more positive than that of the $\mathrm{Mg}$ alloy sheet, which increases about $24 \%$. In addition, from the polarization curves parameters (Table 3 ), $i_{\text {corr }}$ values of the Ti sheet, $\mathrm{Mg}$ alloy sheet and clad plate are $8.61 \times 10^{-9} \mathrm{~A} / \mathrm{cm}^{2}, 1.17 \times 10^{-5} \mathrm{~A} / \mathrm{cm}^{2}$ and $5.72 \times 10^{-9} \mathrm{~A} / \mathrm{cm}^{2}$, respectively. The $i_{\text {corr }}$ value of the clad plate is 4 orders of magnitude lower than that of $\mathrm{Mg}$ alloy sheet. These results indicate the corrosion resistance of the clad plate is much higher than that of the Mg alloy sheet [25,26]. However, some differences are noted between the original Ti sheet and the clad plate. $E_{\text {corr }}$ value of the Ti layer in the clad plate is more negative compared with the Ti sheet. The value shows an about $20 \%$ decrease. In other words, the corrosion resistance of the Ti material after explosive welding decreases. The phenomenon needs to be investigated in future. Although a reduction in corrosion resistance occurred in the clad plate compared with the original Ti sheet, the clad plate showed a higher corrosion resistance than that of the $\mathrm{Mg}$ alloy sheet. Thus, cladding $\mathrm{Mg}$ alloy and Ti by explosive welding would help improve the industrial applications of magnesium materials.

Table 3. Values of parameters from polarization curves of original Ti sheet, $\mathrm{Mg}$ alloy sheet and clad plate (titanium layer as working surface) in $3.5 \% \mathrm{NaCl}$ solution.

\begin{tabular}{ccc}
\hline Materials & $\boldsymbol{E}_{\text {corr }}(\mathbf{m V})$ & $\boldsymbol{i}_{\text {corr }}\left(\mathbf{A} / \mathbf{c m}^{2}\right)$ \\
\hline Ti sheet & -746.1 & $8.61 \times 10^{-9}$ \\
Mg alloy sheet & -1177.7 & $1.17 \times 10^{-5}$ \\
Clad plate & -896.3 & $5.72 \times 10^{-9}$ \\
\hline
\end{tabular}




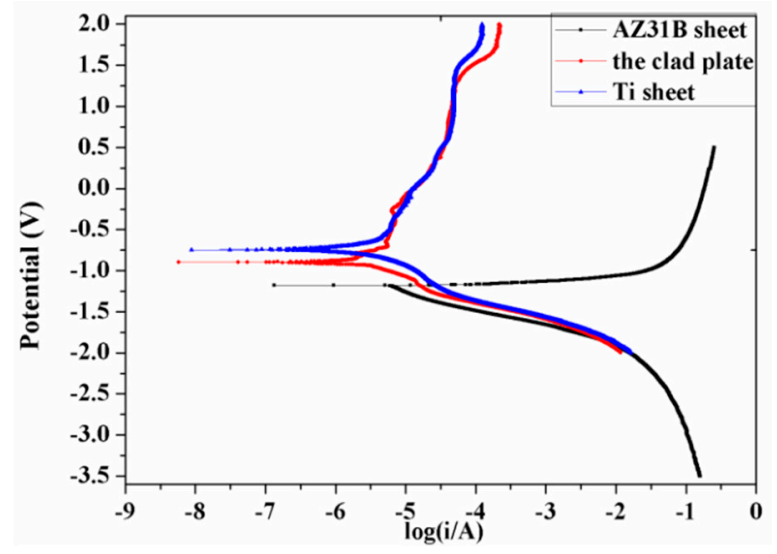

Figure 9. Polarization curves of the three samples in $3.5 \% \mathrm{NaCl}$ solution.

\section{Conclusions}

In this paper, $\mathrm{Ti}$ and $\mathrm{Mg}$ alloy sheets were joined successfully by explosive welding. Ultrasonic examination (US) results showed that the interface reflection wave was obtained, which indicated that the $\mathrm{Ti}$ and $\mathrm{Mg}$ layers were tightly joined together. Then, the interface microstructure, mechanical properties and corrosion resistance of clad plate were investigated. The most important results of this paper are summarized as follows:

(1) The interface of the $\mathrm{Ti} / \mathrm{Mg}$ alloy plate is made up of both straight areas and wavy areas. In straight areas, the element diffusion occurs across the interface. Additionally, in wavy areas, a melting zone occurs in the $\mathrm{Mg}$ alloy layer near to the interface. Lots of light particles embed on the melting zone. The compositions of these particles are $\mathrm{Mg}, \mathrm{Al}, \mathrm{Ti}$ and $\mathrm{O}$ elements. Based on the EDS analysis results, the possible phases of $\mathrm{MgTi}$ and $\mathrm{Mg}_{2} \mathrm{Ti}$ are formed in particles.

(2) Tensile test shows that the ultimate tensile strength of the clad plate is $377 \mathrm{MPa}$. Compared with the Ti sheet, the clad plate shows an $18 \%$ increase. The shearing strength values of the clad plate are about 68-87 MPa. The microhardness values of clad plate are higher than original sheets from the interface to $300 \mu \mathrm{m}$ away. At over $300 \mu \mathrm{m}$, the hardness value decreases, and approaches that of the original sheets. Compared with the straight areas in the interface, the hardness value of the $\mathrm{Mg}$ alloy layer in the wavy areas close to the interface increases by $12 \%$.

(3) Corrosion results show that the $E_{c o r r}$ absolute value of the clad plate increases about $24 \%$, and the $i_{\text {corr }}$ value is 4 orders of magnitude lower, compared with the Mg alloy sheet. This indicates that the corrosion resistance of the clad plate is better than the $\mathrm{Mg}$ alloy. Cladding $\mathrm{Mg}$ alloys and Ti by explosive welding would improve the industrial applications of magnesium materials.

Author Contributions: Conceptualization, H.Z. and L.S.; methodology, C.Z. and L.X.; software, K.Z.; validation, Y.Y. and Y.W.; formal analysis, H.Z. and C.Z.; investigation, H.Z., Y.L. and M.H.; resources, G.Z.; data curation, C.Z. and Y.Y.; writing-original draft preparation, Y.W.; writingreview and editing, H.Z. and L.S.; visualization, C.Z.; supervision, H.Z.; project administration, H.Z.; funding acquisition, H.Z. and M.H. All authors have read and agreed to the published version of the manuscript.

Funding: Natural Science Basic Research Program of Shaanxi (Program No. 2021JM-403, 2021JQ-604); Xi'an Science and Technology Plan Project (Program No. 2020KJRC0100), Scientific Research Program Funded by Shaanxi Provincial Education Department (Program No. 21JC027); Xi'an Shiyou University College Students' Innovation and Entrepreneurship Training Project (Program No. S202010705122, 202110705032), National Natural Science Foundation of China: 5210011310.

Institutional Review Board Statement: Not applicable.

Informed Consent Statement: Not applicable. 
Data Availability Statement: Some or all data, models, or code that support the findings of this study are available from the corresponding author upon reasonable request.

Acknowledgments: All authors acknowledge the support of Funding.

Conflicts of Interest: The author declares there are no conflict of interest regarding the publication of this paper.

\section{References}

1. Du, B.N.; Hu, Z.Y.; Wang, J.L.; Sheng, L.Y.; Zhao, H.; Zheng, Y.F.; Xi, T.F. Effect of extrusion process on the mechanical and in vitro degradation performance of a biomedical Mg-Zn-Y-Nd alloy. Bioact. Mater. 2020, 5, 219-227. [CrossRef]

2. $\quad$ Li, H.; Shi, L.X.; Zhou, T.; Li, M.G.; Chen, Q.; Yang, M.B. A visco-plastic self-consistent analysis of tailored texture on plastic deformation behavior of AZ31 magnesium alloy sheet. J. Mater. Sci. 2021, 56, 19199-19215.

3. Zu, G.Y.; Sun, X.; Zhang, J.H. Interfacial Bonding Mechanism and Mechanical Performance of Ti/Steel Bimetallic Clad Sheet Produced by Explosive Welding and Annealing. Rare Met. Mater. Eng. 2017, 46, 906-911.

4. $\quad$ Li, X.D.; Qiu, C.Y.; Liu, Y.T.; Wang, H.F.; Zheng, D.D.; Zhu, Y.Y.; Zhang, S.Q. Effect of thermal deformation on microstructure and properties of TC18 titanium alloy produced by laser additive manufacturing. J. Iron Steel Res. Int. 2020, 27, 1476-1484. [CrossRef]

5. Arisova, V.N.; Trykov, Y.P.; Slautin, O.V.; Ponomareva, I.A.; Kondakov, A.E. Effect of heat treatment on mechanical properties and phase composition of magnesium-aluminum composite prepared by explosive welding. Met. Sci. Heat Treat. 2015, 57, 291-295. [CrossRef]

6. Chen, P.W.; Feng, J.R.; Zhou, Q.; An, E.F.; Li, J.B.; Yuan, Y. Investigation on the Explosive Welding of 1100 Aluminum Alloy and AZ31 Magnesium Alloy. J. Mater. Eng. Perform. 2016, 25, 2635-2641. [CrossRef]

7. Mróz, S.; Gontarz, A.; Drozdowski, K.; Bala, H.; Szota, P. Forging of Mg/Al bimetallic handle using explosive welded feedstock. Arch. Civ. Mech. Eng. 2018, 18, 401-412. [CrossRef]

8. Rouzbeh, A.; Sedighi, M.; Hashemi, R. Comparison between explosive welding and roll-bonding processes of AA1050/Mg AZ31B bilayer composite sheets considering microstructure and mechanical properties. J. Mater. Eng. Perform. 2020, 29, 6322-6333. [CrossRef]

9. Habib, M.; Keno, H.; Uchida, R. Cladding of titanium and magnesium alloy plates using energy-controlled underwater three layer explosive welding. J. Mater. Process. Technol. 2015, 217, 310-316. [CrossRef]

10. Zhang, T.T.; Wang, W.X.; Zhou, J.; Cao, X.Q.; Yan, Z.F.; Wei, Y.; Zhang, W. Investigation of Interface Bonding Mechanism of an Explosively Welded Tri-Metal Titanium/Aluminum/Magnesium Plate by Nanoindentation. JOM Miner. Met. Mater. Soc. 2018, 70, 504-510. [CrossRef]

11. Zhao, H.; Sheng, L.Y. Microstructure and mechanical properties of the Ag/316L composite plate fabricated by explosive welding. J. Manuf. Process. 2021, 64, 265-275. [CrossRef]

12. Zhao, H. Characterization of the microstructure and bonding properties of zirconium-carbon steel clad materials by explosive welding. Scanning 2020, 5, 8881898. [CrossRef] [PubMed]

13. Zhao, $\mathrm{H}$. The microstructure and property of a titanium-carbon steel clad plate prepared using explosive welding. Metals 2022, 12, 129-138. [CrossRef]

14. Zhao, H.; Zhu, L.; Li, P.C.; Zhang, J.Y.; Shen, C.Y.; Li, Y.; Hao, H.W.; Zhao, F.; Feng, H.L.; Gao, J.F. A Method for Dynamic Parameters of Metal Plate Explosive. Welding. Patent CN201610137182.6, 21 November 2017.

15. Pouraliakbar, H.; Khalaj, G.; Jandaghi, M.R.; Fadaei, A.; Sun, I. Three-layered SS321/AA1050/AA5083 explosive welds: Effect of PWHT on the interface evolution and its mechanical strength. Int. J. Press. Vessel. Pip. 2020, 188, 104216. [CrossRef]

16. Crossland, B. Explosive Welding of Metals and Its Application; Oxford University Press: Oxford, UK, 1982.

17. Mousavi, S.; Sartangi, P.F. Materials design. Experimental investigation of explosive welding of cp-titanium/AISI 304 stainless steel. Mater. Des. 2009, 30, 459-468. [CrossRef]

18. Murray, J.L. ASM Handbook, Volum 3, Alloy Phase Diagrams; ASM International: New York, NY, USA, 1992.

19. Kuz'min, E.V.; Lysak, V.I.; Kuz'min, S.V.; Korolev, M.P. Effect of Parameters of High-Velocity Collision on the Structure and Properties of Joints upon Explosive Welding with Simultaneous Ultrasonication. Phys. Met. Metallogr. 2019, 120, 197-203. [CrossRef]

20. Rajani, H.; Mousavi, S. The role of impact energy in failure of explosive cladding of Inconel 625 and steel. J. Fail. Anal. Prev. 2012, 12, 646-653. [CrossRef]

21. Jiang, H.T.; Yan, X.Q.; Liu, J.X.; Duan, X.G. Effect of heat treatment on microstructure and mechanical property of Ti-steel explosive-rolling clad plate. Trans. Nonferrous Met. Soc. China 2014, 24, 697-704. [CrossRef]

22. Sun, Z.R.; Shi, C.; Xu, F.; Feng, K.; Wu, X. Detonation process analysis and interface morphology distribution of double vertical explosive welding by SPH 2D/3D numerical simulation and experiment. Mater. Des. 2020, 191, 108-117. [CrossRef]

23. Wang, D.; Cao, X.; Wang, L.; Cao, M.; Wang, W. Influence of hot rolling on the interface microstructure and mechanical properties of explosive welded Mg/Al composite plates. J. Mater. Res. 2017, 32, 863-873. [CrossRef]

24. Wu, J.Q.; Wang, W.X.; Cao, X.Q.; Zhang, N. Interface Bonding Mechanism and Mechanical Behavior of AZ31B/TA2 Composite Plate Cladded by Explosive Welding. Rare Met. Mater. Eng. 2017, 46, 640-645. 
25. Tang, Y.B.; Shen, X.W.; Liu, Z.H.; Qiao, Y.X.; Yang, L.L.; Lu, D.H.; Zou, J.S.; Xu, J. Corrosion Behaviors of Selective Laser Melted Inconel 718 Alloy in NaOH Solution. Acta Metall. Sin. 2022, 58, 324-333.

26. Yi, X.N.; Ma, A.L.; Zhang, L.M.; Zheng, Y.G. Crystallographic anisotropy of corrosion rate and surface faceting of polycrystalline 90Cu-10Ni in acidic $\mathrm{NaCl}$ solution. Mater. Des. 2022, 215, 110429. [CrossRef] 